\title{
Spermatocele Mimicking Hydrocele: A Case Report in a Young Patient of 42 Years Old
}

\author{
MZYIENE Mohammed ${ }^{1}$, ZIBA Ouima Justin Dieudonné ${ }^{2}$, MARRAKCHI Jaafar ${ }^{3}$, ENNACIRI Soufiane ${ }^{4}$, \\ EL-AMMARI Jalal Eddine ${ }^{5}$, FARIH Moulay Hassan ${ }^{6}$ \\ 1,2,3,4,5,6 Urology Division, CHU Hassan 2, Fez, Morroco
}

\begin{abstract}
A spermatocele is a cyst-like mass that usually forms on the epididymis; they are benign cystic accumulations of sperm. Depending on their size, they can mimic a hydrocele clinically and radiologically. We report the case of a giant spermatocele in a 42-year-old married. The patient had fathered two children with no fertility problem. This spermatocele gradually increases in volume for 4 years and requires surgical management in front of the scrotal pain and functional gene presented by the patient. Through this case, we present the diagnostic difficulty, the therapeutic approach through a literature review on the subject.
\end{abstract}

KEYWORDS: Hydrocele, Spermatocele, Testicular Tumor, Epididymis Cyst, Spermatic Cord Twisting, Giant Spermatocele

\section{INTRODUCTION}

Spermatocele is a fluid-filled cyst that develops at the head of the epididymis. The fluid is usually a clear or milky white color that may contain sperm [1]. The clinical manifestation of small size spermatocele is sometimes asymptomatic, it can also grow over time and become troublesome, even painful, requiring surgical management. We report here the case of a spermatocele is a 42-year-old patient consulting for a scrotal pain of progressive occurrence, having required surgical management with a review of the literature on this pathology.

\section{CASE REPORT}

A 42-year-old patient with no particular pathological history, married and father of two children received unilateral testicular swelling of progressive evolving for 4 years, increasing in size, becoming painful. At the clinical examination of the patient increased bursary, volume was noted, the right testes were of normal appearance and on the left, and there was an aspect of left hydrocele associated with a positive Trans-lumination. The sperm analysis was normal. At testicular ultrasound: both testicles are normal size $17.1 \mathrm{ml}$ for the right testicle and $23.2 \mathrm{ml}$ for the left testicle. The right epididymis looks normal. Presence of a large left epididymis cyst with thin wall, an echogenic content, measuring $69 \times 36 \mathrm{~mm}$ in diameter. Bilateral hydrocele of low abundance. Absence of visible varicocele. In front of the functional gene and the patient's complaints, surgery was indicated. The patient was admitted under spinal anesthesia. An ipsilateral incision on the left Bursary with testicle used as a log, dissection of the different scrotal envelopes, an exploration noted a fluid cyst located on the top of the testis, epididymis and extending to the spermatic cord (figure 1A). No hydrocele blade was noted as mentioned in the ultrasound report. The procedure consisted of excision of the cyst (Figure 1B) without damaging the spermatic cord and maintaining the integrity of the testis. Plane-by-plane closure of the scrotum after reintroduction of the scrotal contents in place. The piece was sent to anatomy pathology for histology-anatomy-pathological study and the results were in favor of cystic partitioning contained spermatic fluid associated with spermatic cells. The diagnosis was in favor of a rare giant spermatocele.

\section{DISCUSSION}

The name "spermatocele" is from Guerin 1785 who discovered it. It has designated it as a pathology of insidious onset and slow, painless, and unilateral growth. Etiologically, many situations can explain its occurrence knowledge of a spermatocele can develop after trauma, infectious damage to the testis, inguinoscrotal surgery, and vasectomy, and can also be an idiopathic cause. According to the known hypothesis, the occurrence of spermatocele may be due to an obstruction of the efferent ducts resulting in proximal dilatation by seminiferous excretions accumulating throughout life. Spermatocele would therefore be a cystic accumulation of semen, which occurs from puberty, and most often revealed in the fourth and fifth decades in humans. 


\section{International Journal of Current Science Research and Review}

ISSN: 2581-8341

Volume 04 Issue 05 May 2021

DOI: 10.47191/ijcsrr/V4-i5-15, Impact Factor: 5.825

IJCSRR@ 2021

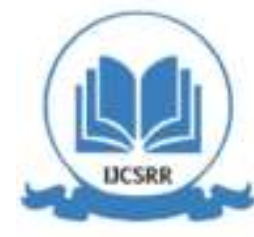

www.ijcsrr.org

The age range of onset of cystic lesions is between 65 and 74 years. Spermatocele usually occurs around the age of 65 according to the epidemiological study by Karl-Johan Lundström[1]. In our case reported, the age of the patient is 42 years. In the case report of Hsin-Chih Yeh, the patient was 55 years old [2].

The spermatocele is usually incipient evolution not requiring complaint and small size. In this case, the patient's lesion progressed over 4 years, gradually increasing in volume until it became uncomfortable for him.

It is important to differentiate spermatocele from other testicular diseases namely hydrocele, epididymis cysts, testicular tumors. The evidence of spermatozoids in the cystic fluid makes it possible to distinguish it from an epididymis cyst, moreover, the spermatocele develops on the posterior side of the testis. Usually, the difference between an epididymis cyst and a spermatocele is at the waist level so the epididymis cystic masses that are greater than $2 \mathrm{~cm}$ are usually called spermatoceles [3,4].

In terms of the management of this condition, there is still no clear codification for this. Most sperm cells do not require treatment if they are not bothersome to the patient. [5]. Sclerotherapy of spermatocele is more effective, simple in achieving with few complications and good cost-effectiveness and can be performed especially in patients with fertility disorders. In the case of our patient, we performed surgical removal of the spermatocele, our patient did not require paternity and already had two children. His sperm analysis before the surgery was normal.

\section{CONCLUSION}

Spermatocele is a relatively rare cystic disease of the testis. It is usually small in size, asymptomatic and evolutionary overage. Its localization and the contents of the cyst make the difference with epididymis cysts. Its management varies depending on its impact on the patient. It is important to think of a spermatocele in front of a cystic condition of the testis of more than $2 \mathrm{~cm}$ in size.

\section{ACKNOWLEDGEMENTS}

We would like to thank Professors, AHSAINI Mustapha, MELLAS Soufiane, TAZI Mohammed Fadl, and ELFASSI Mohammed Jamal for their assistance and guidance in this paper.

\section{REFERENCES}

1. Lundström K-J, Söderström L, Jernow H, Stattin P, Nordin P. Epidemiology of hydrocele and spermatocele; incidence, treatment and complications. Scand J Urol. 2019 May 4;53(2-3):134-8.

2. Giant spermatocele mimicking hydrocele: a case report - PubMed [Internet]. [cited 2021 Apr 24]. Available from: https://pubmed.ncbi.nlm.nih.gov/17606432/

3. Spermatocele: Pathologic and Surgical Anatomy | JAMA Surgery | JAMA Network [Internet]. [cited 2021 Apr 25]. Available from: https://jamanetwork.com/journals/jamasurgery/article-abstract/560653

4. Extra scrotal spermatocele causing lower abdominal pain: a first case report | Request PDF [Internet]. [cited 2021 Apr 25]. Available from:

https://www.researchgate.net/publication/45439124_Extra_scrotal_spermatocele_causing_lower_abdominal_pain_a_first _case_report

5. Shakiba B, Heidari K, Jamali A, Afshar K. Aspiration and sclerotherapy versus hydrocoelectomy for treating hydroceles. Cochrane Kidney and Transplant Group, editor. Cochrane Database Syst Rev [Internet]. 2014 Nov 13 [cited 2021 Apr 24]; Available from: http://doi.wiley.com/10.1002/14651858.CD009735.pub2 


\section{International Journal of Current Science Research and Review}

ISSN: 2581-8341

Volume 04 Issue 05 May 2021

DOI: 10.47191/ijcsrr/V4-i5-15, Impact Factor: 5.825

IJCSRR @ 2021

www.ijjesrr.org


Figure 1. Spermatocele 1A: Intra-Operative Image Showing Left Giant Spermatocele (S) on the insertion of the testicular head (T) 1B: an image of spermatocele fluid.

Cite this Article: MZYIENE Mohammed, ZIBA Ouima Justin Dieudonné, MARRAKCHI Jaafar, ENNACIRI Soufiane, ELAMMARI Jalal Eddine, FARIH Moulay Hassan (2021). Spermatocele Mimicking Hydrocele: A Case Report in a Young Patient of 42 Years Old. International Journal of Current Science Research and Review, 4(5), 422-424 